\title{
2 or 4 sessions of counselling reduced occurrence of sexılally transmitted diseases
}

${ }_{K a m b} \mathrm{ML}$, Fishbein M, Douglas JM. Ir, et al., for the Project RESPECT Study Group. Efficacy of risk-reducjon counseling to prevent human inmunodeficiency virus and sexually transmitted diseases. A randomized controlled trial. JAMA. 1998 Ort 7;280:1161-7.

\section{Question}

In persons attending sexually transmitted disease (STD) clinics, does counselling reduce high-risk sexual behaviour and prevent new STDs?

\section{Design}

Randomised, unblinded, controlled trial with 12-month follow-up.

\section{Selting}

5 inner-city STD clinics in the United States.

\section{Participants}

5758 participants who were $\geq 14$ years of age (median age $25 \mathrm{y}, 57 \% \mathrm{men}$ ), attended 1 of the clinics for an STD examination, and agreed to have an HIV test. Exclusion criteria were men who reported having a male sex partner in the past 12 months or who were bisexual or homosexual, or persons with poor command of English. $82 \%$ of participants completed all assigned intervention sessions.

\section{Intervention}

Participants were allocated to enhanced counselling ( 4 sessions) based on reasoned action and social cognitive theory $(n=1438)$; brief counselling ( 2 sessions) based on the Centers for Disease Control HIV counseling model $(n=1447)$; didactic messages (2 sessions) about HTV and STD prevention $(n=1443)$; or didactic messages with no follow-up sessions scheduled after the intervention ( $n=1430)$. Participants were given U.S. $\$ 15$ for each intervention session attended after the initial session.

\section{Main outcome measure \\ Incidence of new STDs.}

\section{Main results}

Analysis was by intention to treat. Enhanced or brief counselling led to fewer new STDs than did didactic messages at 6 months $\{P \leq 0.006\}^{*}$ and at 12 months $\{P \leq 0.04\}^{*}$ (Table). The enhanced and brief counselling groups had similar cumnlative incidences of STDs.

\section{Conclusion}

2 or 4 sessions of interactive counselling were effective in redicing new STDs in persons attending STD dinics.

Source of funding: Not stated

For conrespondence: Office of Communications, NCHSTP, Matlstop E-06, Centers for Disease Control and Prevention, 1600 Clifton Road Northeast, Atlanta, GA 30333, USA. $F A X$ 404-639-2029

*P values calculated from data in article.

Enhanced and brief counselling vs didactic messages for preventing new sexually transmitted diseases $\dagger$

\begin{tabular}{lccccc}
\hline New STDs & Enhanced & Brief & Didactic & RRR $(95 \%$ CI $)$ & NNT (C) \\
\hline At 6 mo & $7.2 \%$ & - & $10.4 \%$ & $31 \%(12$ to 45$)$ & $32(19$ to 90$)$ \\
& - & $7.3 \%$ & $10.4 \%$ & $28 \%(9.3$ to 45$)$ & $34(20$ to 116$)$ \\
At 12 mo & $11.5 \%$ & - & $14.6 \%$ & $22 \%(5.1$ to 35$)$ & $32(18$ to 145$)$ \\
& - & $12.0 \%$ & $14.6 \%$ & $18 \%(1.4$ to 32$)$ & $38(19$ to 522$)$ \\
\hline
\end{tabular}

$\uparrow S T D=$ sextally transmitted disease. Other abbreviations defined in Glossary; RRR, NNT, and $\mathrm{Cl}$ calculated from chata in aricle.

\section{Commentary}

The study by Kamb and colleagues is 1 of 6 recent randomised controlled trials that have cratuated whether social and behavioutal interventions are effective in reducing selfreported risk behaviours and STD incidence (I-4; J. Parsonnet. Personal communication.). Al 6 studies show that behavioural interventons can have a measurable effect in lowering the risk for STDs among high-risk sudy participants, atthough each study used slightly different approaches to changing behaviours. Thes, behaviourally based STD and HIV prevention programs have been shown by evidence from high-quality studies to reduce selfreported unsafe behaviors and STD incilence in a variety of populations. Some linitations exist, however. Current knowledge is primarily based on followy-up intervals of $\leq 1$ year. The outcones measured are usually selfmre- ported change of risk behaviours or ancillary sexually transmitted infections and nor HTV. Thus, we have a crucial need for large studies evaluating behavioural interventions to determine whether the reduction of unsafe behaviours and the lowering of other sexuatly transmitted infections can act as appropriate surrogates for decreasing HTV acquisition.

The study by Kamb and colleagues supports clinical recornmendations to provide clientcentred counselling as an essential element of HIV prevention programs, but counselling must be part of a more comprebensive HIV prevention strategy in which complemen tary approaches reinforce each other to contain the epidemic.

Willow Cates, $7 \pi, M D, M P H$

Family Healtb thtemational

Research Triangle Park, Nortb Carolina, USA

\section{Reforences}

1. NIMH Multisite HIV Prevention Trial Group. The NIMH Multiste HIV Preverttion Tital; reducing HIV sexual risk behavior. Science. 1998;280:1889-94.

2. Sluain RN, Piper JM, Newton ER, et al. A randomized, controlled trial of a behavioral intervention to prevent sexually transmitted disease among minotity women. N Tingl J Med. 1999;340:93-100.

3. Sangiwa $G$, Balmer D, Furlonge C, et al. Voluntary IITV counselling and testing (VCT) reduces risk behavior in developing countries: resuits from the voluntary counselling and testing stady. Int Conf AIDS. $1998 ; 12: 646$.

4. Celentano $\mathrm{DD}$, Bond $\mathrm{KC}$, $\mathrm{Na}$ Chiang $M C$, et al, Interventions among Thai conscripts may reduce HIV incidence. Natl Conf Hurn Retroviruses Relat Infect (2nd). $1995 \mathrm{Jan} 29-\mathrm{Feb}$ 2:57 